\title{
A cytomorphological and immunohistochemical profile of aggressive B-cell lymphoma: high clinical impact of a cumulative immunohistochemical outcome predictor score
}

\author{
Sylvia Höller • Heike Horn • Andreas Lohr • Uwe Mäder • Tiemo Katzenberger • \\ Jörg Kalla • Heinz-Wolfram Bernd • Philip Went • M. Michaela Ott • \\ Hans Konrad Müller-Hermelink • Andreas Rosenwald • German Ott
}

Received: 22 July 2009 /Accepted: 11 August 2009/Published online: 2 September 2009

(C) Springer-Verlag 2009

\begin{abstract}
We analyzed morphological and immunohistochemical features in 174 aggressive B-cell lymphomas of nodal and extranodal origin. Morphological features included presence or absence of a follicular component and cytologic criteria according to the Kiel classification, whereas immunohistochemical studies included expression of CD10, BCL-2, BCL-6, IRF4/MUM1, HLA-DR, p53, Ki-67 and the assessment of plasmacytoid differentiation. Patients were treated with a CHOP-like regimen. While the presence or absence of either CD10, BCL-6 and IRF4/MUM1 reactivity or plasmacytoid differentiation did not identify particular cytomorphologic or site-specific subtypes, we found that expression of CD10 and BCL-6, and a low reactivity for IRF4/MUM1 were favourable prognostic indicators. In contrast, BCL-2 expres-
\end{abstract}

Andreas Rosenwald and German Ott are joint senior authors.

S. Höller · A. Lohr · T. Katzenberger · H. K. Müller-Hermelink ·

A. Rosenwald

Department of Pathology, University of Würzburg,

Würzburg, Germany

S. Höller · P. Went

Department of Pathology, Kantonsspital Basel,

University of Basel,

Basel, Switzerland

H. Horn · J. Kalla $\cdot$ G. Ott

Department of Clinical Pathology, Robert-Bosch-Krankenhaus, and Dr. Margarete Fischer-Bosch-Institute of Clinical

Pharmacology, University of Tübingen,

Stuttgart, Germany

U. Mäder

Comprehensive Cancer Center Mainfranken,

University of Würzburg,

Würzburg, Germany sion and presence of a monotypic cytoplasmic immunoglobulin expression was associated with an unfavourable prognosis in univariate analyses. Meta-analysis of these data resulted in the development of a cumulative immunohistochemical outcome predictor score (CIOPS) enabling the recognition of four distinct prognostic groups. Multivariate analysis proved this score to be independent of the international prognostic index. Such a cumulative immunohistochemical scoring approach might provide a valuable alternative in the recognition of defined risk types of aggressive B-cell lymphomas.

Keywords Diffuse large B-cell lymphoma - Aggressive B-cell lymphoma $\cdot$ Prognosis · Immunohistochemistry

H.-W. Bernd

Department of Pathology,

Universitätsklinikum Schleswig-Holstein,

Campus Lübeck,

Lübeck, Germany

M. M. Ott

Department of Pathology, Caritas-Krankenhaus, Bad Mergentheim, Germany

G. Ott $(\bowtie)$

Abteilung Pathologie, Robert-Bosch-Krankenhaus,

Auerbachstrasse 110,

70376 Stuttgart, Germany

e-mail: german.ott@rbk.de 


\section{Introduction}

Diffuse large B-cell lymphomas (DLBCL) comprise a heterogeneous category of malignant Non-Hodgkin lymphomas (NHL) with respect to morphology, immunophenotype, genetic features, and clinical course [1]. The striking differences regarding outcome, especially, have prompted the assumption that this lymphoma type includes different disease entities and that their delineation might allow the assignment of tailored treatment approaches to defined risk profiles. These attempts, in the past, aimed at the assessment of morphological criteria, such as the separation of immunoblastic and centroblastic types [2], the evaluation of genetic aberrations [3] and certain biological features, such as the proliferation index [4-6], or the expression of relevant proteins like BCL-2 [7-11].

Gene expression profiling using cDNA and oligonucleotide microarrays proved to be a powerful tool both in the delineation of two main differentiation phenotypes in DLBCL, namely a germinal center (GC) B-cell like and an activated B-cell like (ABC) DLBCL type, as well as in the recognition of prognostically relevant gene expression profiles [12-14]. The striking clinical impact of distinguishing GC- and non-GC types of DLBCL, demonstrated in the CHOP-, but more recently also in the R-CHOP treatment era [15], led to the search of individual genes or smaller numbers of genes the expression of which might facilitate their recognition in order to make this approach amenable to routine diagnostic practice [16-19]. This approach also includes the widely used Hans-algorithm [17]. However, a number of studies provided highly variable and conflicting data questioning their suitability to define robust clinical risk groups [16, 17, 20-29]. By investigating well known markers which correlate with a germinal center or postgerminal center differentiation (CD10, BCL-6, IRF4/ MUM1) as well as other markers of potential prognostic importance $[17,30,31]$ we constructed, as a new approach, a cumulative immunohistochemical outcome predictor score resulting in the delineation of four distinct prognostic groups.

\section{Material and methods}

Specimen selection

Inclusion of samples required the availability of diagnostic material (paraffin blocks) and that the patient had not been treated before biopsy. Therefore, samples from patients with known preceding low-grade lymphoma were excluded. Material from 166 DLBCL patients fulfilled these criteria. Of these, 10 DLBCL had an additional follicular lymphoma grade 3B (DLBCL + FL3B) component, and 13 tumors harbored an additional FL3A area. Because of their striking morphological, immunophenotypic and genetic similarities with diffuse large
B cell lymphomas [32], we also included 8 purely follicular lymphomas grade 3B (FL3B). Thus, altogether, specimens from 174 patients with aggressive large B-cell tumors diagnosed between 1990 and 2003 were enrolled in this study. Clinical data were available from referring clinicians in all patients (Table 1). All patients, with a single exception, were treated with a CHOP or CHOP-like chemotherapy regimen. The study was approved by the Local Ethics Committee of the University of Würzburg, Germany.

Nodal and extranodal origin of tumors

The large majority of lymphomas arose in the lymph nodes, while other lymphatic organs primarily infiltrated were the spleen in six cases and the pharyngeal tonsil in another six cases. 28 tumors presented with primary extranodal origin, the majority of them $(n=17)$ in the stomach but also in the thyroid gland (6 cases), the small and large intestine ( 3 cases), the breast and sinus maxillaries (1 case each).

Table 1 Major clinical features of the patient cohort

\begin{tabular}{|c|c|}
\hline Clinical parameter & No. of patients \\
\hline \multicolumn{2}{|l|}{ Gender } \\
\hline Male & 92 \\
\hline Female & 81 \\
\hline N/A & 1 \\
\hline \multicolumn{2}{|l|}{ Age (y) } \\
\hline Median (range) & $63(8-94)$ \\
\hline No more than 60 & 73 \\
\hline More than 60 & 100 \\
\hline N/A & 1 \\
\hline \multicolumn{2}{|l|}{ Ann Arbor stage } \\
\hline I & 26 \\
\hline II & 29 \\
\hline III & 35 \\
\hline IV & 31 \\
\hline N/A & 53 \\
\hline \multicolumn{2}{|l|}{ LDH } \\
\hline Normal & 42 \\
\hline High & 74 \\
\hline N/A & 58 \\
\hline \multicolumn{2}{|l|}{ IPI group } \\
\hline Low $(0-1)$ & 38 \\
\hline Intermediate (2-3) & 37 \\
\hline High (4-5) & 13 \\
\hline Not classified & 86 \\
\hline \multicolumn{2}{|l|}{ B Symptoms } \\
\hline Yes & 49 \\
\hline No & 70 \\
\hline N/A & 55 \\
\hline Median follow-up (range) & 33 months (1-163) \\
\hline
\end{tabular}


Morphology

All cases were reviewed on whole tissue sections stained for Hematoxylin and Eosin, Giemsa, Periodic acid-Schiff (PAS) and Gomori's silver impregnation. Diagnoses were made according to the criteria of the WHO classification of 2008 and, in addition, variants were described according to the criteria of the Kiel classification in diagnosing centroblastic-monomorphic, centroblastic-multilobated and centroblastic-polymorphic lymphomas [33]. In DLBCL with an additional FL3 component, the presence of follicular dendritic cell networks was confirmed by immunostaining using appropriate antibodies (CD21, CD23), and follicular structures had to be present in at least $25 \%$ of the infiltrated areas.

\section{Immunohistochemistry}

For diagnostic purposes, immunostaining was performed on paraffin sections using B-cell markers CD20 (Clone L26, DAKO, Glostrup, Denmark, 1:1000) and CD23 (Clone 1B12, NOVOCASTRA, Newcastle upon Tyne, United Kingdom, 1:80) and T-cell markers CD3 (NOVOCASTRA, 1:80) and CD5 (Clone 4C7, NOVOCASTRA, 1:40). Proliferation indices (PI) were estimated in areas with the highest reactivity and recorded in increments of $10 \%$ after staining with the MIB1 antibody (MM1, NOVOCASTRA, 1:30) detecting the Ki67 antigen. The expression of CD10 was assessed using the antibody NCL-CD10 270 (NOVOCASTRA, 1:100). BCL-6 was detected using the PG-B6p antibody (DAKO, 1:20) and IRF4/MUM1 staining involved the MUM1p antibody (DAKO, 1:8000), also evaluated in increments of $10 \%$. HLA-DR expression was analyzed using clone IQU9 (NOVOCASTRA, 1:80).

The expression of p53 was investigated on paraffin sections using the DO-7 antibody (DAKO, 1:40). To score a case as positive, strong nuclear expression in at least $20 \%$ of cells was required. To assess plasmacytoid differentiation $(\mathrm{CIg}+)$, intracytoplasmic immunoglobulin was detected with antibodies to kappa and lambda light chains and in some cases to IgM (all DAKO, 1:20000). An unequivocal monotypic cytoplasmic reactivity was required to score a case as CIg+. BCL-2 expression was evaluated on paraffin sections using the antibody from DAKO (Clone 124, $1: 400)$. A reactivity of $>20 \%$ of cells was regarded as positive. The presence of follicular dendritic cell (FDC) meshworks was ascertained either by staining for CD23 (Clone 1B12, NOVOCASTRA, 1:80) or by using an antibody to CD21 (Clone 1F8, DAKO, 1:200). All immunohistochemical reactions on paraffin were performed using the peroxidase anti-peroxidase (PAP) method after antigen retrieval [34]. The quantitative assessment of immunohistochemical staining evaluation was performed according to the scoring guidelines recommended by de Jong and co-workers [35].

\section{Statistical analyses}

Frequencies in different parameters were compared and analysed using the chi-square test, t-test for independent variables, or other appropriate tests, respectively, depending on the nature of data. Overall survival (OS) was measured from the date of diagnosis to death from any cause or to last follow-up. OS distributions were calculated according to the methods described by Kaplan and Meier. Time to event distributions were compared using the log-rank test. A multivariate analysis including the risk factors of the international prognostic index (IPI) was carried out to determine independent predictors of survival by using the Cox proportional hazard model for survival analysis and Pearson's correlation. A $p$ value of $<0.05$ was regarded as statistically significant.

\section{Results}

\section{Clinical data}

Clinical data were available for all patients listed in Table 1 . Age distribution showed a peak in the 7th decade with a slight male predominance. The patients presented with advanced disease (Ann Arbor stages III and IV) in more than half of the cases. The median follow up time was 33 months ranging from 1 month to 163 months.

\section{Primary localization of lymphomas and morphology}

132 lymphomas arose in lymph nodes, while in 12 additional cases the largest and/or only tumor mass was found in the tonsil or spleen, respectively (6 cases each). Two tumors involved the bone marrow exclusively, with leukemic spread. 28 DLBCL presented with a primary extranodal localization. The stomach was the most frequent extranodal site involved (17 cases), while the other sites were the thyroid gland $(n=6)$, the small and large intestine $(n=3)$, the breast, and the maxillary sinus ( $n=1$ each). 143 tumors were pure DLBCL, while 23 cases had a detectable follicular component. Ten cases were classified as DLBCL with a FL3B component, and 13 DLBCL showed an additional FL3A component (most of them with a multilobated cytology). Eight lymphomas were purely follicular FL3B. All extranodal tumors were classified as DLBCL.

All lymphomas with a predominantly diffuse component (i.e. DLBCL \pm minor FL component) involving lymph nodes, spleen or tonsils were subclassified according to the Kiel classification as centroblastic-monomorphic and/or 
centroblastic-multilobated (63 cases), centroblasticpolymorphic (28 cases) and immunoblastic (24 cases) lymphomas.

\section{Immunophenotypes}

Due to loss of material, complete immunophenotypes were available in 145 cases. CD10 was expressed in 57/145 evaluable cases $(39 \%)$. In contrast to this antigen, that was usually either homogeneously present or absent on all tumor cells, both BCL-6 and IRF4/MUM1 reactivities varied considerably ranging from $0 \%$ to $100 \%$ of cells in a given tumor. A high expression of BCL- 6 in $\geq 70 \%$ of nuclei, like in the reactive germinal center (GC) was encountered in $73(50 \%)$ lymphomas, while 43 tumors $(30 \%)$ showed an intermediate reactivity $(20 \%-60 \%)$. No or low levels of BCL-6 expression $(<20 \%)$ were seen in 27 tumors. IRF4/MUM1 was positive in $\geq 50 \%$ of nuclei in 45 cases $(31 \%)$. BCL-2 was expressed in 100 lymphomas (69\%). The Ki-67 antigen was expressed in $\geq 80 \%$ of nuclei in 82 tumors $(57 \%)$. A monotypic cytoplasmic immunoglobulin expression could be detected in 62 of $145(43 \%)$ cases. P53 was overexpressed ( $\geq 20 \%$ positive tumour cells) in 29 of $143(20 \%)$ DLBCL. HLA-DR expression was present in 121 of 124 cases (98\%). Only 3 cases showed no expression $(<10 \%$ of cells $)$.

\section{Heterogeneity of immunophenotypes}

In contrast with the rather ordered immunophenotypic profile encountered in the various compartments of reactive lymphoid tissues, the expression of immunophenotypic markers was highly heterogeneous in the lymphoma cases. For example, BCL-2 was expressed in 37/57 (65\%) CD10 positive tumors, in comparison with 63/88 (72\%) CD10 negative cases; seven CD10-positive tumors (12\%) also expressed the post-germinal marker IRF4/MUM1 in at least $50 \%$ of cells.

Overall, there was a strong positive correlation between the expression of CD10 and BCL-6, while CD10 positivity was negatively correlated with MUM1 reactivity. In highly proliferative tumours (Ki-67 index $\geq 80 \%$ ), there were more lymphomas with BCL-6 expression (44/54) and CD10 expression (34/54). In contrast, tumors with proliferation indices $<80 \%$ harbored fewer cases with a GC phenotype, but were more often IRF4/MUM1 and BCL-2 positive.

There was a wide distribution of the different morphologic subtypes within the GC-related and non-GC-related lymphomas according to the Hans classifier [17]. 37/44 (84\%) multilobated centroblastic lymphomas (CB) were GCB DLBCL, as were all multilobated centroblastic DLBCL with a FL3A component. Only 16/27 (59\%) of the centroblastic polymorphic DLBCL were of GCB type. In contrast, 18/21 (86\%) immunoblastic lymphomas (IB) were non-GCB related. It is interesting to note that among tumors other than multilobated centroblastic cases, purely follicular FL3B tumors were more often of GCB type (6 GCB, 2 non-GCB), while DLBCL with a FL3B component predominantly fell into the non-GCB group ( $3 \mathrm{GCB}, 7$ nonGCB). Primarily extranodal lymphomas were GCB $(n=13)$ and non-GCB $(n=14)$ types in equal distribution.

\section{Correlations with survival}

Within 145 lymphomas with a complete immunophenotype, 121 tumors with nodal, splenic or tonsillar involvement and 24 primarily extranodal DLBCL had follow-up data available. Adverse clinical variables with regard to overall survival (OS) were elevated LDH levels $(p<0.001)$, presence of B symptoms $(p=0.002)$, and age $>60$ years $(p=0.04)$. The IPI also was a powerful outcome predictor $(p<0.001)$.

Neither the presence of a (partly) follicular growth pattern $(p=0.9)$, nor the primary site of involvement (nodal/extranodal) predicted survival $(p=0.7$ ).

In univariate analysis, the following immunohistochemical parameters predicted an unfavourable prognosis: BCL2 expression irrespective of staining intensity $(p<0.001)$, CD10 negativity $(p<0.02)$, BCL- 6 expression in $<20 \%$ of cells $(p<0.001)$, IRF4/MUM1 reactivity in $\geq 50 \%$ of nuclei $(p<0.02)$, and monotypic cytoplasmic immunoglobulin expression $(\mathrm{CIg}+)(p<0.03)$. In addition, in the present series, stratification of the tumors into GC-related and nonGC-related types according to the criteria described by Hans et al. [17] was predictive of survival and showed a GC differentiation to represent a favourable parameter $(p<0.01$; Fig. 1). Univariate analyses of HLA-DR and

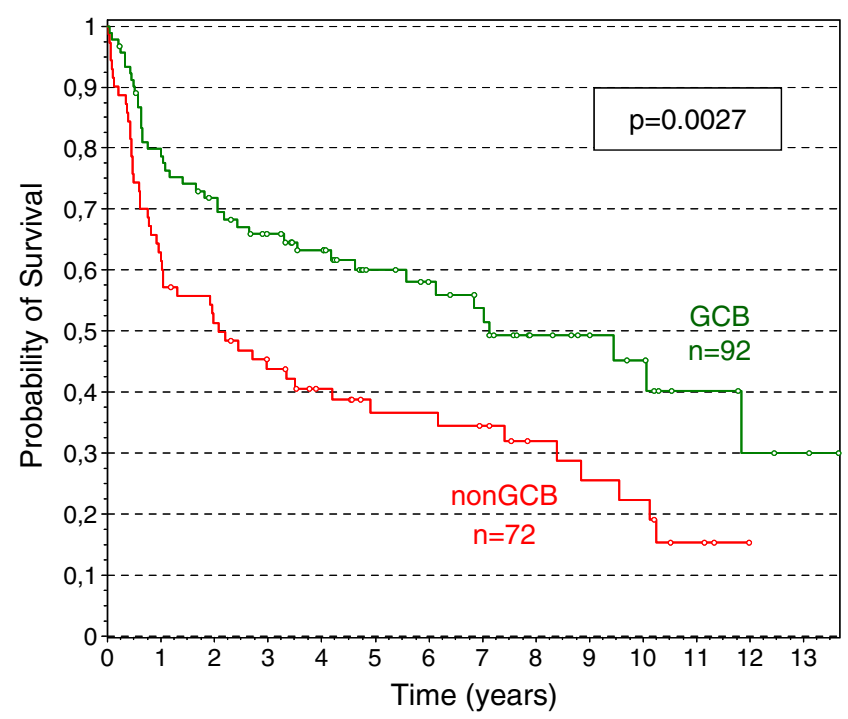

Fig. 1 Stratification of the tumors according to the Hans algorithm was predictive of survival and showed a GC differentiation to represent a favourable parameter in the Kaplan-Meier model 


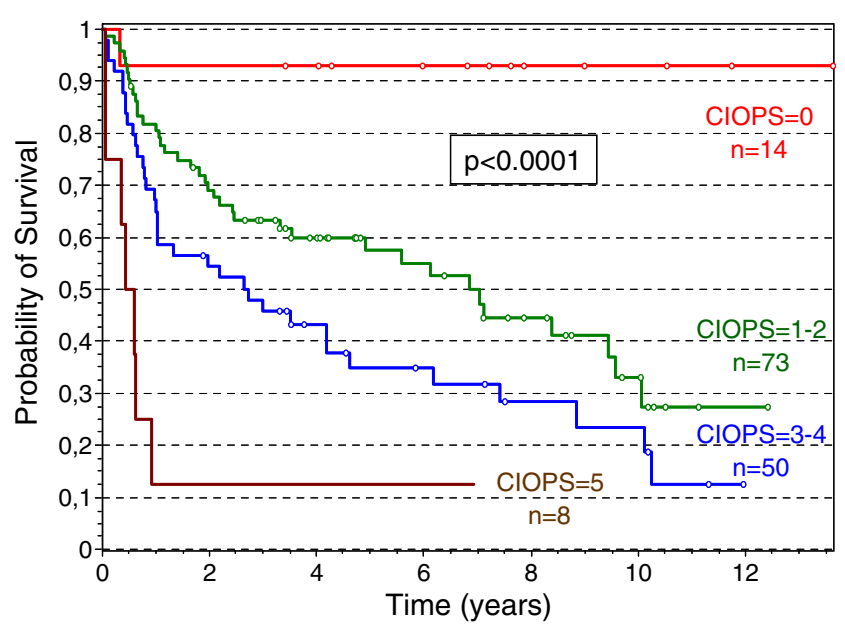

Fig. 2 Overall survival of all 145 patients stratified according to the CIOPS score with a dramatic difference in survival between cases without risk factors (score null), cases with 1-2 adverse prognostic factors, cases with 3-4 adverse prognostic factors, and cases with a score of five

p53 expression and the proliferation index failed to yield statistically significant correlations with survival.

Development of a cumulative immunohistochemical outcome predictor score (CIOPS)

To test whether the patients could be more accurately categorized into favourable and poor-risk groups we devised a cumulative scoring system based on the sequential addition of negative prognostic indicators in a given tumor (cumulative immunohistochemical outcome predictor score: CIOPS). Each variable that emerged as prognostically negative in univariate analysis (CD10 negativity, BCL-6 expression in $<20 \%$, BCL-2 positivity, MUM1/ IRF4 expression in $\geq 50 \%$, cytoplasmic immunoglobulin expression) was scored as one negative factor, and the sum of negative factors resulted in a risk score that ranged from zero to five in each given case.

When the prognostic effect of the score was analyzed in the 145 patients using the Kaplan-Meier model, a dramatic difference in survival was recognized between cases without risk factors (score: zero), cases with 1-2 adverse prognostic factors, cases with 3-4 adverse prognostic factors, and cases with a score of five $(p<0.0001$; Fig. 2).

In the favourable prognostic group with 14 patients, all patients except for one survived. Review of the medical report indicated that this patient was an 80-year old woman who, after diagnosis, refused further treatment. In contrast, in the group with a CIOPS score of five 7 of 8 patients died (the surviving patient was a 65 year old male with an initial Ann Arbor stage 2 and an IPI of 2, follow up time 83 months). The survival curves of the remaining 123 patients with intermediate scores (1-4) were also different with the possibility to distinguish a favorable intermediate (scores 1-2) and a poor intermediate group (scores 3-4) that show significant differences in survival $(p=0.0398)$. In multivariate analysis, the cumulative immunohistochemical outcome predictor score proved to be independent of the IPI index, including age, stage of disease, elevated serum LDH, B-symptoms and extranodal manifestation.

Table 2 gives an overview of the distribution of the immunophenotypes in the different CIOPS subgroups. As can be seen from this table, the immunohistochemical features dividing the tumors into CIOPS groups 2 and 3 were variable. Using the algorithm of Hans et al. [17] CIOPS group 2 contained 61 GCB and 12 non-GCB cases, and group 3 contained 40 non-GCB and 10 GCB cases. The two most important features that discriminated between the groups 1 and 2 were more frequent BCL-2 positivity or CD10 negativity in group 2. Monotypic cytoplasmic immunoglobulin expression or IRF4/MUM1 expression was a classifying feature in group 3.

No morphological subtypes clustered within a distinct CIOPS group. Those immunoblastic lymphomas, for whom immunohistochemistry was available $(n=10)$, were more or less equally distributed among different CIOPS groups (CIOPS 2: 2 cases; CIOPS 3: 3 cases; CIOPS 4: 2 cases; CIOPS 5: 1 case), although none were found in low CIOPS group.

Table 2 Overview of the distribution of the immunophenotypes in the different CIOPS subgroups

\begin{tabular}{lllllllll}
\hline $\begin{array}{l}\text { CIOPS } \\
\text { group }\end{array}$ & $\begin{array}{l}\text { CIOPS- } \\
\text { Score }\end{array}$ & $\begin{array}{l}\text { number } \\
\text { of cases }\end{array}$ & $\begin{array}{l}\text { nonGCB/ } \\
\text { GCB }\end{array}$ & $\begin{array}{l}\text { CD10 positive/ } \\
\text { negative }\end{array}$ & $\begin{array}{l}\text { BCL-6 positive/ } \\
\text { negative }\end{array}$ & $\begin{array}{l}\text { cIg positive/ } \\
\text { negative }\end{array}$ & $\begin{array}{l}\text { BCL-2 positive/ } \\
\text { negative }\end{array}$ & $\begin{array}{l}\text { MUM1p } \\
\text { positive/ } \\
\text { negative }\end{array}$ \\
\hline 1 & 0 & 14 & $0 / 14$ & $14 / 0(100 / 0 \%)$ & $14 / 0(100 / 0 \%)$ & $0 / 14(0 / 100 \%)$ & $0 / 14(0 / 100 \%)$ & $0 / 14(0 / 100 \%)$ \\
2 & 1 & 42 & $5 / 37$ & $28 / 14(67 / 33 \%)$ & $40 / 0$ & $4 / 38(10 / 90 \%)$ & $24 / 18(57 / 43 \%)$ & $2 / 40(5 / 95 \%)$ \\
& 2 & 31 & $7 / 24$ & $11 / 20(55 / 45 \%)$ & $29 / 2(94 / 6 \%)$ & $13 / 18(42 / 48 \%)$ & $24 / 7(77 / 23 \%)$ & $3 / 28(10 / 90 \%)$ \\
3 & 3 & 24 & $14 / 10$ & $4 / 20(20 / 80 \%)$ & $18 / 6(75 / 25 \%)$ & $14 / 10(58 / 42 \%)$ & $20 / 4(83 / 17 \%)$ & $12 / 12(50 / 50 \%)$ \\
& 4 & 26 & $26 / 0$ & $0 / 26(0 / 100 \%)$ & $15 / 11(58 / 42 \%)$ & $23 / 3(88 / 12 \%)$ & $24 / 2(92 / 8 \%)$ & $20 / 6(77 / 23 \%)$ \\
4 & 5 & 8 & $8 / 0$ & $0 / 8(0 / 100 \%)$ & $0 / 8(0 / 100 \%)$ & $8 / 0(100 / 0 \%)$ & $8 / 0(100 / 0 \%)$ & $8 / 0(100 / 0 \%)$ \\
\hline
\end{tabular}




\section{Discussion}

Diffuse large B-cell lymphomas comprise a heterogeneous group of lymphoid tumors with varying morphology, immunophenotypes, genetic characteristics, and clinical course. Previous studies have aimed at the more accurate definition of their risk profiles using different criteria such as morphology [2, 36, 37], protein expression patterns targeting several proliferation or apoptosis related antigens $[4,5,7-11,38,39]$ or their genetic constitution [3, 40, 41].

Because of the conflicting data resulting from earlier studies on the value of immunohistochemical marker expression in DLBCL [17, 20, 22, 25, 42, 43], we applied a novel, slightly different approach and constructed a cumulative immunohistochemical outcome predictor score (CIOPS) to divide DLBCL patients into various risk groups. Following the notion that-in contrast to normal B-cell differentiation - dual expression of both GC-related and GC-unrelated markers [e.g. BCL-6 and IRF4/MUM1 [44]] can be frequently observed in the same tumor, the immunohistochemical assignment to the GCB- or non-GCB group appears problematic.

In the present study, the combined analysis of antigens having been related to either a germinal center differentiation of normal reactive and tumor cells, such as CD10 and BCL-6, or pointing to a postfollicular differentiation step (IRF4/MUM1, plasmacytoid differentiation) has clearly confirmed the heterogeneity of antigen expression patterns in DLBCL as compared with compartments of the reactive lymphoid tissues [44-47]. Nevertheless, statistical analysis revealed a strong positive correlation of CD10 and BCL-6 expression on one hand, and of IRF4/ MUM1 expression and plasmacytoid differentiation on the other hand. Moreover, in univariate analysis, expression of both CD10 and BCL-6 identified prognostically relevant favourable subgroups, while IRF4/MUM1 reactivity in $50 \%$ or more of tumor cells characterized tumors with an inferior prognosis. In our study, two additional features were of value for identifying risk groups, namely the expression of BCL-2 and the assessment of plasmacytoid differentiation of the tumor cells. While the negative prognostic impact of BCL-2 expression in DLBCL is well established [7-11], few studies have addressed the possible importance of plasmacytoid differentiation in DLBCL. Simonitsch-Klupp and colleagues [48] demonstrated that plasmablastic/plasmacytoid differentiation represents a significant risk factor in DLBCL. Immunoblastic morphology, which frequently goes along with plasmacytoid differentiation, has been repeatedly identified as a risk factor in DLBCL [2, 37]. The prognostic importance of plasmacytoid differentiation using the analysis of kappa and lambda light chain expression in the cytoplasm of the tumor cells, however, has not been evaluated so far.

Given the promiscuous expression of GC- and non-GC related proteins in a subset of DLBCL which makes the strict categorization into GCB and non-GCB DLBCL groups difficult at the immunohistochemical level, we investigated the possible clinical impact of a model that sequentially adds risk markers rather than basing risk assessments on decision trees. Specifically, by assigning equal weights to each of the immunophenotypic features identified in univariate analysis, we developed a cumulative immunohistochemical outcome predictor score (CIOPS). To each case, an individual risk score from zero to five is attributed which is based on prognostically negative factors including the absence of CD10 expression, BCL- 6 reactivity in $<20 \%$ of cells, IRF4/MUM1 positivity in $\geq 50 \%$ of nuclei, BCL-2 expression, and plasmacytoid differentiation of the tumor cells. Plotting the survival of the different patient cohorts according to the CIOPS group revealed four highly distinct survival curves with a low-risk group consisting of patients characterized by a score of zero, patients with a high-risk score of 5 with a dismal course and two intermediate groups with CIOPS scores 1 and 2 and 3 and 4, respectively. Multivariate analysis comparing the CIOPS score to the IPI stressed its independent prognostic value in clinical risk assessment. Besides the delineation of four distinct prognostic subgroups, the CIOPS score also identifies two patient cohorts at the extremes of the spectrum with striking differences in the mortality rates (7\% vs. $100 \%$ ) which might be a valuable feature towards future risk adapted therapeutic strategies. Clearly, any prognostic significance of the CIOPS score has to be studied in the context of an independent study cohort with an increased number of patients suffering from DLBCL.

One major caveat to the interpretation of these data is that the investigated patient cohort stems from the preRituximab era. However, a recent major gene expression profiling study suggests that many molecular features with prognostic significance in the CHOP treatment era are retained in the CHOP-R treatment era [15]. Therefore, studies that are already under way will have to determine whether our cumulative immunohistochemical model might also be of predictive value in patient cohorts treated with current protocols.

Acknowledgements The expert technical assistance of H. Brückner, S. Roth, P. Stempfle, S. Groh, C. Rudolph, and K. Schroedl is gratefully acknowledged. We also thank E. Schmitt for artful photographic work. We are indebted to our clinical colleagues for providing clinical data, especially to R. Kuse and R. Sonnen, Hamburg, and to M. Wilhelm, Nürnberg and U. Gunzer, Würzburg.

$\mathrm{AR}$ is supported by the Interdisciplinary Center for Clinical Research (IZKF), University of Würzburg. GO and HH are supported by the Robert-Bosch-Stiftung. 


\section{References}

1. Swerdlow SH, Campo E, Harris NL, Jaffe ES, Pileri SA, Stein H, Thiele J, Vardiman JW (eds) (2008) World Health Organization Classification of Tumours of Haematopoietic and Lymphoid tissues. International Agency for Research on Cancer, Lyon

2. Engelhard M, Brittinger G, Huhn D, Gerhartz HH, Meusers P, Siegert W, Thiel E, Wilmanns W, Aydemir U, Bierwolf S, Griesser H, Tiemann M, Lennert K (1997) Subclassification of diffuse large B-cell lymphomas according to the Kiel classification: distinction of centroblastic and immunoblastic lymphomas is a significant prognostic risk factor. Blood 89:2291-2297

3. Schlegelberger B, Zwingers T, Harder L, Nowotny H, Siebert R, Vesely M, Bartels H, Sonnen R, Hopfinger G, Nader A, Ott G, Muller-Hermelink K, Feller A, Heinz R (1999) Clinicopathogenetic significance of chromosomal abnormalities in patients with blastic peripheral B-cell lymphoma. Kiel-Wien-Lymphoma Study Group. Blood 94:3114-3120

4. Grogan TM, Lippman SM, Spier CM, Slymen DJ, Rybski JA, Rangel CS, Richter LC, Miller TP (1988) Independent prognostic significance of a nuclear proliferation antigen in diffuse large cell lymphomas as determined by the monoclonal antibody Ki-67. Blood 71:1157-1160

5. Silvestrini R, Costa A, Boracchi P, Giardini R, Rilke F (1993) Cell proliferation as a long-term prognostic factor in diffuse large-cell lymphomas. Inter J Cancer 54:231-236

6. Wilson WH, Teruya-Feldstein J, Fest T, Harris C, Steinberg SM, Jaffe ES, Raffeld M (1997) Relationship of p53, bcl-2, and tumor proliferation to clinical drug resistance in non-Hodgkin's lymphomas. Blood 89:601-609

7. Gascoyne RD, Adomat SA, Krajewski S, Krajewska M, Horsman DE, Tolcher AW, O'Reilly SE, Hoskins P, Coldman AJ, Reed JC, Connors JM (1997) Prognostic significance of Bcl-2 protein expression and $\mathrm{Bcl}-2$ gene rearrangement in diffuse aggressive non-Hodgkin's lymphoma. Blood 90:244-251

8. Hermine O, Haioun C, Lepage E, d'Agay MF, Briere J, Lavignac C, Fillet G, Salles G, Marolleau JP, Diebold J, Reyas F, Gaulard P (1996) Prognostic significance of bcl-2 protein expression in aggressive non-Hodgkin's lymphoma. Groupe d'Etude des Lymphomes de l'Adulte (GELA). Blood 87:265-272

9. Hill ME, MacLennan KA, Cunningham DC, Vaughan HB, Burke M, Clarke P, Di SF, Anderson L, Vaughan HG, Mason D, Selby P, Linch DC (1996) Prognostic significance of BCL-2 expression and bcl-2 major breakpoint region rearrangement in diffuse large cell non-Hodgkin's lymphoma: a British National Lymphoma Investigation Study. Blood 88:1046-1051

10. Kramer MH, Hermans J, Parker J, Krol AD, Kluin-Nelemans JC, Haak HL, van GK, van Krieken JH, De JD, Kluin PM (1996) Clinical significance of bcl 2 and $\mathrm{p} 53$ protein expression in diffuse large B-cell lymphoma: a population-based study. J Clin Oncol 14:2131-2138

11. Kramer MH, Hermans J, Wijburg E, Philippo K, Geelen E, van Krieken JH, De JD, Maartense E, Schuuring E, Kluin PM (1998) Clinical relevance of BCL2, BCL6, and MYC rearrangements in diffuse large B-cell lymphoma. Blood 92:3152-3162

12. Alizadeh AA, Eisen MB, Davis RE, Ma C, Lossos IS, Rosenwald A, Boldrick JC, Sabet H, Tran T, Yu X, Powell JI, Yang L, Marti GE, Moore T, Hudson J Jr, Lu L, Lewis DB, Tibshirani R, Sherlock G, Chan WC, Greiner TC, Weisenburger DD, Armitage JO, Warnke R, Levy R, Wilson W, Grever MR, Byrd JC, Botstein D, Brown PO, Staudt LM (2000) Distinct types of diffuse large Bcell lymphoma identified by gene expression profiling. Nature 403:503-511

13. Rosenwald A, Wright G, Chan WC, Connors JM, Campo E, Fisher RI, Gascoyne RD, Muller-Hermelink HK, Smeland EB,
Giltnane JM, Hurt EM, Zhao H, Averett L, Yang L, Wilson WH, Jaffe ES, Simon R, Klausner RD, Powell J, Duffey PL, Longo DL, Greiner TC, Weisenburger DD, Sanger WG, Dave BJ, Lynch JC, Vose J, Armitage JO, Montserrat E, Lopez-Guillermo A, Grogan TM, Miller TP, LeBlanc M, Ott G, Kvaloy S, Delabie J, Holte H, Krajci P, Stokke T, Staudt LM (2002) The use of molecular profiling to predict survival after chemotherapy for diffuse large-B-cell lymphoma. N Engl J Med 346:1937-1947

14. Shipp MA, Ross KN, Tamayo P, Weng AP, Kutok JL, Aguiar RC, Gaasenbeek M, Angelo M, Reich M, Pinkus GS, Ray TS, Koval MA, Last KW, Norton A, Lister TA, Mesirov J, Neuberg DS, Lander ES, Aster JC, Golub TR (2002) Diffuse large B-cell lymphoma outcome prediction by gene-expression profiling and supervised machine learning. Nat Med 8:68-74

15. Lenz G, Wright G, Dave SS, Xiao W, Powell J, Zhao H, Xu W, Tan B, Goldschmidt N, Iqbal J, Vose J, Bast M, Fu K, Weisenburger DD, Greiner TC, Armitage JO, Kyle A, May L, Gascoyne RD, Connors JM, Troen G, Holte H, Kvaloy S, Dierickx D, Verhoef G, Delabie J, Smeland EB, Jares P, Martinez A, Lopez-Guillermo A, Montserrat E, Campo E, Braziel RM, Miller TP, Rimsza LM, Cook JR, Pohlman B, Sweetenham J, Tubbs RR, Fisher RI, Hartmann E, Rosenwald A, Ott G, MullerHermelink HK, Wrench D, Lister TA, Jaffe ES, Wilson WH, Chan WC, Staudt LM (2008) Stromal gene signatures in large-B-cell lymphomas. N Engl J Med 359:2313-2323

16. Barrans SL, Carter I, Owen RG, Davies FE, Patmore RD, Haynes AP, Morgan GJ, Jack AS (2002) Germinal center phenotype and bcl-2 expression combined with the International Prognostic Index improves patient risk stratification in diffuse large B-cell lymphoma. Blood 99:1136-1143

17. Hans CP, Weisenburger DD, Greiner TC, Gascoyne RD, Delabie J, Ott G, Muller-Hermelink HK, Campo E, Braziel RM, Jaffe ES, Pan Z, Farinha P, Smith LM, Falini B, Banham AH, Rosenwald A, Staudt LM, Connors JM, Armitage JO, Chan WC (2004) Confirmation of the molecular classification of diffuse large B-cell lymphoma by immunohistochemistry using a tissue microarray. Blood 103:275-282

18. Lossos IS, Jones CD, Warnke R, Natkunam Y, Kaizer H, Zehnder JL, Tibshirani R, Levy R (2001) Expression of a single gene, BCL-6, strongly predicts survival in patients with diffuse large B-cell lymphoma. Blood 98:945-951

19. Uherova P, Ross CW, Schnitzer B, Singleton TP, Finn WG (2001) The clinical significance of CD10 antigen expression in diffuse large B-cell lymphoma. Am J Clin Pathol 115:582-588

20. Berglund M, Thunberg U, Amini RM, Book M, Roos G, Erlanson M, Linderoth J, Dictor M, Jerkeman M, Cavallin-Stahl E, Sundstrom C, Rehn-Eriksson S, Backlin C, Hagberg H, Rosenquist R, Enblad G (2005) Evaluation of immunophenotype in diffuse large B-cell lymphoma and its impact on prognosis. Mod Pathol 18:1113-1120

21. Biasoli I, Morais JC, Scheliga A, Milito CB, Romano S, Land M, Pulcheri W, Spector N (2005) CD10 and Bcl-2 expression combined with the International Prognostic Index can identify subgroups of patients with diffuse large-cell lymphoma with very good or very poor prognoses. Histopathology 46:328-333

22. Colomo L, Lopez-Guillermo A, Perales M, Rives S, Martinez A, Bosch F, Colomer D, Falini B, Montserrat E, Campo E (2003) Clinical impact of the differentiation profile assessed by immunophenotyping in patients with diffuse large B-cell lymphoma. Blood 101:78-84

23. Haarer CF, Roberts RA, Frutiger YM, Grogan TM, Rimsza LM (2006) Immunohistochemical classification of de novo, transformed, and relapsed diffuse large B-cell lymphoma into germinal center B-cell and nongerminal center B-cell subtypes correlates with gene expression profile and patient survival. Arch Pathol Lab Med 130:1819-1824 
24. Muris JJ, Meijer CJ, Vos W, van Krieken JH, Jiwa NM, Ossenkoppele GJ, Oudejans JJ (2006) Immunohistochemical profiling based on Bcl-2, CD10 and MUM1 expression improves risk stratification in patients with primary nodal diffuse large $\mathrm{B}$ cell lymphoma. J Pathol 208:714-723

25. Natkunam Y, Farinha P, Hsi ED, Hans CP, Tibshirani R, Sehn LH, Connors JM, Gratzinger D, Rosado M, Zhao S, Pohlman B, Wongchaowart N, Bast M, Avigdor A, Schiby G, Nagler A, Byrne GE, Levy R, Gascoyne RD, Lossos IS (2008) LMO2 protein expression predicts survival in patients with diffuse large B-cell lymphoma treated with anthracycline-based chemotherapy with and without rituximab. J Clin Oncol 26:447-454

26. Nyman H, Adde M, Karjalainen-Lindsberg ML, Taskinen M, Berglund M, Amini RM, Blomqvist C, Enblad G, Leppa S (2007) Prognostic impact of immunohistochemically defined germinal center phenotype in diffuse large B-cell lymphoma patients treated with immunochemotherapy. Blood 109:4930-4935

27. Sjo LD, Poulsen CB, Hansen M, Moller MB, Ralfkiaer E (2007) Profiling of diffuse large B-cell lymphoma by immunohistochemistry: identification of prognostic subgroups. Eur J Haematol 79:501-507

28. Xu Y, McKenna RW, Molberg KH, Kroft SH (2001) Clinicopathologic analysis of CD10+ and. Am J Clin Pathol 116:183-190

29. Zinzani PL, Dirnhofer S, Sabattini E, Alinari L, Piccaluga PP, Stefoni V, Tani M, Musuraca G, Marchi E, Falini B, Baccarani M, Pileri SA (2005) Identification of outcome predictors in diffuse large B-cell lymphoma. Immunohistochemical profiling of homogeneously treated de novo tumors with nodal presentation on tissue micro-arrays. Haematologica 90:341-347

30. Rimsza LM, Roberts RA, Miller TP, Unger JM, LeBlanc M, Braziel RM, Weisenberger DD, Chan WC, Muller-Hermelink HK, Jaffe ES, Gascoyne RD, Campo E, Fuchs DA, Spier CM, Fisher RI, Delabie J, Rosenwald A, Staudt LM, Grogan TM (2004) Loss of MHC class II gene and protein expression in diffuse large B-cell lymphoma is related to decreased tumor immunosurveillance and poor patient survival regardless of other prognostic factors: a follow-up study from the Leukemia and Lymphoma Molecular Profiling Project. Blood 103:4251-4258

31. Visco C, Canal F, Parolini C, Andreoli A, Ambrosetti A, Krampera M, Lestani M, Pizzolo G, Chilosi M (2006) The impact of P53 and P21(wafl) expression on the survival of patients with the germinal center phenotype of diffuse large B-cell lymphoma. Haematologica 91:687-690

32. Ott G, Katzenberger $\mathrm{T}$, Lohr A, Kindelberger S, Rudiger $\mathrm{T}$, Wilhelm M, Kalla J, Rosenwald A, Muller JG, Ott MM, MullerHermelink HK (2002) Cytomorphologic, immunohistochemical, and cytogenetic profiles of follicular lymphoma: 2 types of follicular lymphoma grade 3. Blood 99:3806-3812

33. Lennert K, Feller A (1992) Histopathology of Non-Hodgkin's Lymphomas. Springer Verlag, New York

34. Rudiger T, Hofler H, Kreipe HH, Nizze H, Pfeifer U, Stein H, Dallenbach FE, Fischer HP, Mengel M, von WR, MullerHermelink HK (2002) Quality assurance in immunohistochemistry: results of an interlaboratory trial involving 172 pathologists. Am J Surg Pathol 26:873-882

35. de Jong D, Rosenwald A, Chhanabhai M, Gaulard P, Klapper W, Lee A, Sander B, Thorns C, Campo E, Molina T, Norton A, Hagenbeek A, Horning S, Lister A, Raemaekers J, Gascoyne RD, Salles G, Weller E (2007) Immunohistochemical prognostic markers in diffuse large B-cell lymphoma: validation of tissue microarray as a prerequisite for broad clinical applications-a study from the Lunenburg Lymphoma Biomarker Consortium. J Clin Oncol 25:805-812
36. de Jong D, Voetdijk BM, Beverstock GC, van Ommen GJ, Willemze R, Kluin PM (1988) Activation of the c-myc oncogene in a precursor-B-cell blast crisis of follicular lymphoma, presenting as composite lymphoma. N Engl J Med 318:1373-1378

37. Diebold J, Anderson JR, Armitage JO, Connors JM, MacLennan KA, Muller-Hermelink HK, Nathwani BN, Ullrich F, Weisenburger DD (2002) Diffuse large B-cell lymphoma: a clinicopathologic analysis of 444 cases classified according to the updated Kiel classification. Leuk Lymphoma 43:97-104

38. Filipits M, Jaeger U, Pohl G, Stranzl T, Simonitsch I, Kaider A, Skrabs C, Pirker R (2002) Cyclin D3 is a predictive and prognostic factor in diffuse large B-cell lymphoma. Clin Cancer Res 8:729-733

39. Kuttler F, Valnet-Rabier MB, Angonin R, Ferrand C, Deconinck E, Mougin C, Cahn JY, Fest T (2002) Relationship between expression of genes involved in cell cycle control and apoptosis in diffuse large B cell lymphoma: a preferential survivin-cyclin B link. Leukemia 16:726-735

40. Jerkeman M, Johansson B, Akerman M, Cavallin-Stahl E, Kristoffersson U, Mitelman F (1999) Prognostic implications of cytogenetic aberrations in diffuse large B-cell lymphomas. Eur J Haematol 62:184-190

41. Offit K, Lo CF, Louie DC, Parsa NZ, Leung D, Portlock C, Ye BH, Lista F, Filippa DA, Rosenbaum A (1994) Rearrangement of the bcl-6 gene as a prognostic marker in diffuse large-cell lymphoma. N Engl J Med 331:74-80

42. de Paepe P, Achten R, Verhoef G, Wlodarska I, Stul M, Vanhentenrijk V, Praet M, De Wolf-Peeters C (2005) Large cleaved and immunoblastic lymphoma may represent two distinct clinicopathologic entities within the group of diffuse large B-cell lymphomas. J Clin Oncol 23:7060-7068

43. van Imhoff GW, Boerma EJ, van der HB, Schuuring E, Verdonck LF, Kluin-Nelemans HC, Kluin PM (2006) Prognostic impact of germinal center-associated proteins and chromosomal breakpoints in poor-risk diffuse large B-cell lymphoma. J Clin Oncol 24:4135-4142

44. Dogan A, Bagdi E, Munson P, Isaacson PG (2000) CD10 and BCL-6 expression in paraffin sections of normal lymphoid tissue and B-cell lymphomas. Am J Surg Pathol 24:846-852

45. de Jong D, Xie W, Rosenwald A, Chhanabhai M, Gaulard P, Klapper W, Lee A, Sander B, Thorns C, Campo E, Molina T, Hagenbeek A, Horning S, Lister A, Raemaekers J, Salles G, Gascoyne RD, Weller E (2009) Immunohistochemical prognostic markers in diffuse large B-cell lymphoma: validation of tissue microarray as a prerequisite for broad clinical applications (a study from the Lunenburg Lymphoma Biomarker Consortium). J Clin Pathol 62:128-138

46. Falini B, Fizzotti M, Pucciarini A, Bigerna B, Marafioti T, Gambacorta M, Pacini R, Alunni C, Natali-Tanci L, Ugolini B, Sebastiani C, Cattoretti G, Pileri S, la-Favera R, Stein H (2000) A monoclonal antibody (MUM1p) detects expression of the MUM1/ IRF4 protein in a subset of germinal center B cells, plasma cells, and activated T cells. Blood 95:2084-2092

47. Falini B, Mason DY (2002) Proteins encoded by genes involved in chromosomal alterations in lymphoma and leukemia: clinical value of their detection by immunocytochemistry. Blood 99:409-426

48. Simonitsch-Klupp I, Hauser I, Ott G, Drach J, Ackermann J, Kaufmann J, Weltermann A, Greinix HT, Skrabs C, Dittrich C, Lutz D, Potter R, Mannhalter C, Lechner K, Chott A, Jaeger U (2004) Diffuse large B-cell lymphomas with plasmablastic/ plasmacytoid features are associated with TP53 deletions and poor clinical outcome. Leukemia 18:146-155 